УДК 378: 37.3.011.3.06-057.87:81 243

DOI: 10.31339/2617-0833-2018-2(25)-175-179

ДІАЛОГІЧНА ТЕХНОЛОГІЯ ФОРМУВАННЯ ЦІННІСНОГО САМОВІДНОШЕННЯ МАЙБУТНЬОГО ВЧИТЕЛЯ ІНОЗЕМНОЇ МОВИ

Сідун М.М., Білак Н.В.

\title{
DIALOGUE TECHNOLOGY FOR THE FORMATION OF THE VALUE-BASED SELF- DENIAL OF THE FUTURE TEACHER OF A FOREIGN LANGUAGE
}

Sidun Marianna, Bilak Nikoletta

У статті розкрито сутність діалогічного підходу в професійній підготовиі майбутнього вчителя іноземної мови, його роль у професійному становленні майбутнього фахівия; проаналізовано форми діалогічної взаємодії викладача і студентів у педагогічному проиесі.

Ключові слова: діалог, діалогічна взаємодія, професійна підготовка майбутнього вчителя початкової школи, діалогічний підхід, модель учителя початкової школи.

Dialogic Approach is in Professional Preparation of Future Teacher of Initial School. In the articleessence of dialogic approach opens up in professionalpreparation of future teacher of initial school; his role is inthe professional becoming of future specialist; the forms ofdialogic cooperation of teacher and students are analy-sedin a pedagogical process. An author marks that mutual relations come forward theinternal condition of dialogic co-operation between a teacherand student, that can be characterized as personality. Dialogic approach in professional preparation of futureteachers of initial school can be realized in the conditions ofequal in rights cooperation of teachers and students; toreadiness of teacher to the dialogue with students; toreadiness of students to the dialogue with teachers.

Keywords: dialogue, dialogue interaction, vocational training of the future teacher of elementary school, dialogical approach, model of teacher of elementary school.

Пошук шляхів оптимізації професійного становлення майбутніх учителів іноземної мови - актуальна й надзвичайно важлива проблема сьогодення, оскільки йдеться не про вдосконалення механічного засвоєння студентами певного обсягу знань, а про формування готовності студентів до творчого їх застосування, майстерного оволодіння професійними вміннями та навичками. Професійна культура майбутнього вчителя формується на основі усвідомлених, оцінних знань, які мають бути мобільними, керованими, адаптованими до умов педагогічної діяльності, а також на основі сформованих діалогічних умінь, які входять до складу i спеціальних, i загальних умінь та визначаються як здатність особистості виконувати складні комплексні дії задля успішної реалізації діяльності, в основі якої лежить діалог. Аналіз шкільної практики й рівня готовності студентів - майбутніх учителів іноземної мови до професійної діяльності - засвідчує потребу розроблення нових моделей $\mathrm{i}$ методик, оскільки традиційні вже недостатньо забезпечують належний рівень їхньої підготовки. А відтак нагальною є проблема дослідження діалогічного підходу в професійній підготовці вчителя іноземної мови.

Підготовка вчителя іноземної мови до успішної професійної діяльності - важлива проблема, яку досліджують різні науки, і насамперед педагогіка. Так, вирішальне значення в дослідженні проблем, пов'язаних із підготовкою вчителя до педагогічної діяльності, мають наукові дослідження О. Абдуліної, І. Богданової, М. Євтуха, В. Кан-Калика, Н. Кузьміної, Н. Ничкало, В. Сластьоніна, О. Щербакова, М. Ярмаченка та ін. Специфіка професійної підготовки вчителя іноземної мови відображена в наукових дослідженнях А. Алексюка, Н. Бібік, В. Бондаря, С. Гончаренка, І. Зязюна, О. Івлєвої, Л. С. Лисенкової, Н. Ничкало, Р. Пріми, О. Савченко, Л. Хомич та ін. Під час дослідження ми встановили, що професіоналізм 
- міра, ступінь опанування i реалізації людиною професійно-посадових вимог та відповідного кваліфікаційного рівня їх виконання. Саме професіоналізм педагога, його професійна педагогічна культура - яскравий результат професійної підготовки та готовності до творчої вчительської праці. Конструктивними в контексті цього дослідження є міркування О. Кіліченко щодо визначення рівня готовності студентів до педагогічної взаємодії як основи педагогічної діяльності за чотирма провідними компонентами: мотиваційним, гносеологічним, аксіологічним, операційним [6]. У свою чергу, Т. Іванова визначає професійно-педагогічну культуру майбутнього вчителя як особистісну інтегративну властивість, особистісне новоутворення, яке містить ціннісний, моральний, креативний, соціальний і технологічний аспекти [3]. Отже, для кожної професії розробляють відповідну модель фахівця, до складу якої входять: професіограма, психограма, професійно-посадові вимоги, кваліфікаційний профіль. За такого розуміння модель фахівця - це аналог його діяльності, виражений у репрезентативних характеристиках, що визначаються в дослідженні умов функціонування сукупності фахівців (М. Пригодій). Над розробленням моделі випускника вищої школи плідно працювали М. Ульязова, О. Смирнова, А. Маркова, С. Чистяков та ін. Найбільш поширені в педагогічній практиці кваліфікаційні характеристики та професіограми. За тлумаченням А. Маркової, професіограма - це науково-обгрунтовані норми й вимоги професії до видів професійної діяльності та якостей особистості фахівця, які дають йому можливість ефективно виконувати вимоги професії, отримувати потрібний для суспільства продукт і водночас створювати умови для розвитку особистості самого працівника [8]. На нашу думку, для педагогічної діяльності особливо значущими $\epsilon$ психограма як опис особистості вчителя в педагогічній професії та трудограма як опис особливостей педагогічної праці в професії вчителя (А. Маркова, С. Чистяков, Н. Захаров). Отже, саме модель фахівця виступає системоутворюючим фактором для відбору змісту освіти й форм його реалізації в навчально-виховному процесі у вищому навчальному закладі. Як свідчать результати цього дослідження, важливим для побудови моделі майбутнього вчителя початкової школи є теоретичний аналіз різних підходів до процесу його професійної підготовки. А тому мета статті - розкрити сутності та особливостей діалогічного підходу до професійної підготовки вчителя іноземної мови.

Аналіз психолого-педагогічної літератури засвідчує, що професійна підготовка вчителя іноземної мови традиційно грунтується на дотриманні насамперед системного, особистісно орієнтованого та діяльнісного підходів. Системний підхід передбачає забезпечення цілісності педагогічного процесу, взаємозв'язку його компонентів, педагогічної системи та особистості. А відтак цей підхід логічно пов'язаний з особистісним, згідно з яким метою і суб' єктом педагогічного процесу є особистість майбутнього фахівця, а, у свою чергу, особистісне та професійне зростання $є$ його результатом. Саме тому особистісний підхід забезпечує визнання особистості студента як найвищої цінності, урахування його інтересів, потреб, переконань, ідеалів в організації навчально-виховного процесу. Оскільки умовою особистісного зростання людини $є$ їі діяльність, то важливим у професійному становленні $\epsilon$ реалізація діяльнісного підходу. Лише в конкретній практичній діяльності можливе професійне становлення майбутнього вчителя іноземної мови. У процесі дослідження ми встановили, що професійна підготовка майбутніх учителів іноземної мови здійснюється на основі суб' єкт-суб'єктної взаємодії, яка грунтується на діалозі їі учасників. Як стверджує I. Бех, діалогічна взаємодія характеризується тим, що активно організуюче ставлення виявляється не лише до предмета спільної діяльності, а й до самого партнера зі спілкування [1]. У цьому контексті Л. Долинська зазначає, що діалогічна взаємодія суб'єктів педагогічного процесу (викладачів і студентів) - складний, полірівневий процес, під час якого здійснюється засвоєння не лише мотиваційно-смислового аспекту педагогічної професії, а й іiі предметно-операційного. Отже, відбувається не лише особистісне, а й професійне зростання. Взаємна зацікавленість один одним активізує самопізнання обох учасників, стимулює процеси самовираження, збагачує новими способами саморозвитку [2]. 
Особливо актуальна діалогічна взаємодія в професійній підготовці вчителя початкової школи. На думку Василя Сухомлинського, справжнім педагогом є лише той, хто в кожному своєму вихованцеві вміє бачити й бачить людину в майбутньому, тобто вчительській праці властива далека перспектива, яка змушує педагога зважувати кожне слово, прораховувати кожен крок, аби не упустити жодного виховного шансу: «Якщо до вас прибіг малюк 3 широко розкритими від тривоги й хвилювання очима, якщо він тремтячим голосом повідомляє, що там твориться зло або може статися зло, - не заспокоюйте його. Заспокоїте раз, другий, третій, а на четвертий раз уже й заспокоювати не треба буде: він до вас не прийде» [9, с. 235]. Учені стверджують, що внутрішньою умовою діалогічної взаємодії виступають взаємини між викладачем та студентом, які можна кваліфікувати як особистісні. Інакше кажучи, такі взаємини характерні для рівноправних партнерів у спілкуванні, які позитивно ставляться один до другого. Ідеться про те, що викладач для студента є носієм цікавої інформації, авторитетною особою, старшим другом, порадником і водночас рівноправним партнером. Студент для викладача відповідно виступає індивідуальністю, яка $\epsilon$ неповторною, цікавою, творчою, також є рівноправним партнером, який не лише поглинає інформацію, а й готовий до обміну нею. За таких умов позиції педагога і студента майбутнього вчителя іноземної мови - особистісно рівноправні. У цьому контексті доцільно зазначити, що важливою є рольова зміна, тобто викладач не просто вчить студента, повчає його, а навпаки, створює такі умови, за яких студент прагне сам пізнавати щось нове, самовдосконалюватись. Отже, якщо діяльнісний підхід, як зазначали ми вище, забезпечує переведення студента в позицію активного суб'єкта пізнання, навчання, спілкування, то діалогічний або ж полісуб'єктний підхід випливає з багатогранності особистості й сприяє розвитку особистісної активності, креативності особистості, іiі самовдосконаленню та саморозвитку. На нашу думку, діалогічний підхід, інтегруючись із діяльнісним та особистісним, слугує методологічним підгрунтям професійної підготовки майбутнього вчителя іноземної мови. Особистість дитини розвивається в умовах взаємовідносин з іншими людьми, побудованих за принципом діалогу. Повернемося знову до педагогічної спадщини Василя Сухомлинського, зокрема до його опису спілкування вчителя 3 дітьми: «Він буває і гнівним, і обуреним, але ніколи не кричить. I не тому, що докладає зусиль, щоб стримати себе. Діти уміють читати в його голосі десятки відтінків почуття: прикрості, тривоги, образи. Так, справжній вихователь переживає глибоке почуття образи, коли діти роблять щось не так. Коли він чимось обурений, він говорить пошепки, і клас прислухається до кожного його слова, затамувавши подих. Це не якась спеціальна постановка, вироблення голосу, ні, це йде від душі, від великої внутрішньої культури й виховання почуттів. Діти повсякденно відчувають на собі найтоншу реакцію багатої почуттями душі свого наставника на свої вчинки, на свою поведінку. Ця реакція іє той могутній засіб виховання в дусі гуманності, без якого немислима школа. Якраз у цій реакції, у цих порухах багатої душі наставника вихованці й відчувають його правдивість» [10, с. 498].

Діалогічний підхід забезпечує особистісно-орієнтований стиль відносин викладача вищої школи і студента. На нашу думку, цей стиль можна назвати гуманно-вимогливим, оскільки викладач бачить перед собою творчу особистість студента, майбутнього фахівця, успішну людину, яка може й має в майбутньому досягти великих успіхів, стати професіоналом своєї справи. Під час дослідження ми встановили, що діалогічний підхід забезпечується при діалогічному спілкуванні, якщо виходити з класифікації К. Митрофанова. Так, автор виділяє вісім стилів спілкування педагога з вихованцями: усунений - закритий від вихованців педагог-функціонер без вираженої індивідуальності; конфліктний - ці педагоги $є$ прихильниками методів покарання та застосування санкцій проти вихованців (різновид авторитарного стилю); потуральний - педагог надає надмірної свободи вихованцям через невпевненість у власних силах, усіляко злагоджують і пом'якшують негативні впливи (аналог ліберального стилю); авторитарно-монологічний - педагог демонстративно показує свою зверхність, упевнений у власній здатності харизматично підкорювати своєю владою 
почуття інших людей, він за будь-яку ціну домагається зовнішнього порядку та ідеальної дисципліни; самозречений - той, хто повністю віддає свою душевну енергетику на користь іншим i, насамперед, вихованцям; такі педагоги зазвичай надто емоційні, імпульсивні; маніпулятивний - ці педагоги цілеспрямовано працюють на результат i досягають поставленої мети; паралельний - педагоги зорієнтовані на навчальну дисципліну, залучають до iï вивчення вихованців, удосконалюючись самі; діалогічний - педагог і студенти спілкуються на партнерських засадах співтворчості та співробітництва. Викладач творить алгоритм взаємодії, співпраці, моделює проблему, яку вони спільно зі студентами конструктивно розв'язують [9]. Якщо ж брати класифікацію спілкування В. Кан-Каліка, то конструктивними для реалізації діалогічного підходу є спілкування на підставі захоплення спільною творчою діяльністю та спілкування, що грунтується на дружньому ставленні до викладача, позитивному особистісному сприйнятті студентами свого педагога [5, с. 97-100].

Практика діяльності вищої школи доводить, що існують й інші стилі спілкування викладачів і студентів: спілкування-дистанція із чітким проявом авторитаризму педагога, спілкування-залякування як гіперавторитаризм, стиль загравання, що часто містить у собі поблажливість i нещирість. Діалогічний підхід у професійній підготовці майбутнього вчителя іноземної мови реалізується також сугестивною дією викладача. Як зазначає Д. Пащенко, кожен педагог є сугестором [7]. Ідеться про те, що як учень вірить своєму вчителеві, так і студент вірить своєму наставникові. Тому головне завдання вищої школи позитивне навіювання студентам викладацького досвіду, професіоналізму, педагогічної майстерності. Під час дослідження ми встановили, що ефективними для забезпечення діалогічного підходу в професійній підготовці майбутнього вчителя іноземної мови $\epsilon$, наприклад, такі діалогічні прийоми взаємодії, як формулювання проблеми для спільного розв'язання; запитання до студентів; можливість вибору завдання та шляхів його розв'язання; звернення до минулого досвіду; оцінювання відповідей колег; рецензування відповідей; самооцінювання та ін. Серед форм організації навчального процесу найбільш ефективні для забезпечення діалогічного підходу проблемна лекція, лекція-розповідь, лекція з мотивацією студентів до іiї вивчення, практичні заняття, семінарські заняття та ін. Висновки і перспективи подальших досліджень.

Діалогічний підхід - один із провідних у професійній підготовці майбутнього вчителя іноземної мови, оскільки саме він забезпечує готовність майбутнього педагога до гуманістичної взаємодії зі школярами, сприяє формуванню гуманістичного та демократичного стилю його взаємин $з$ педагогами, батьками та учнями. Діалогічний підхід сприяє формуванню в майбутніх учителів іноземної мови навичок діалогічного спілкування, основою якого $є$ вміння слухати й чути, визначати в розмові з іншими важливу думку, підтримувати іï, емоційно реагувати, тобто взаємодіяти та взаємовпливати один на одного. Діалогічний підхід у професійній підготовці майбутніх учителів може бути реалізований за таких умов: рівноправної взаємодії викладачів і студентів; готовності викладача до діалогу зі студентами; готовності студентів до діалогу; створення сприятливого діалогічногуманістичного навчально-виховного середовища; включення в навчально-виховний процес ситуацій вибору, проблемних завдань; насичення змісту навчальних предметів творчими й запитально-відповідними завданнями; застосування проблемно-пошукового стилю педагогічного спілкування; залучення студентів до пошукової діяльності; діагностика рівня готовності студентів до діалогічної взаємодії та ін.

Саме науково-педагогічне обгрунтування, вивчення названих нами умов, пошук оптимальних шляхів їх реалізації і потребують подальшого дослідження.

\section{Список використаних джерел}

1. Бех І. Д. Виховання особистості. У 2 кн. Кн. 2 : Особистісно-орієнтований підхід: науково-практичні засади / І. Д. Бех. - К. : Либідь, 2003. - 344 с.

2. Долинська Л. В. Психолого-педагогічні умови ефективної взаємодії викладачів і 
студентів в умовах традиційної освіти / Л. В. Долинська // Наукові записки Ін-ту психології ім. Г. С. Костюка АПН України / за ред. акад. С. Д. Максименка. - К. : Главник, 2005. - Вип. 26, т. 2. - C. $8-11$.

3. Іванова Т. В. Професійна культура майбутнього вчителя / Т. В. Іванова // Педагогіка і психологія. - 1995. - № 2. - С. 86-93.

4. Леонтьев А. А. Педагогическое общение / А. А. Леонтьев. - М. : Знание, 1979. - 48

c.

5. Кан-Калик В. А. Учителю о педагогическом общении / В. А. Кан-Калик. - М. : [б. и.], 1987. $-180 \mathrm{c.}$

6. Кіліченко О. Ігрові методи стимулювання навчально-пізнавальної діяльності майбутніх учителів початкових класів / О. Кіліченко // Школа першого ступеня: Теорія i практика : зб. наук. пр. Переяслав-Хмельн. держ. пед. ун-ту ім. Г. Сковороди / редкол. : В. П. Коцур (гол. ред.) та ін. - Переяслав-Хмельницький : Астон, 2003. - Вип. 7. - С. 184-189.

7. Пащенко Д. І. Генезис гуманістичних ідей у педагогіці: монографія / Д. I. Пащенко. - К. : Науковий світ, 2001. - 278 с.

8. Митрофанов К. Г. Ученичество как реализация субъектности ученика в педагогическом общении / К. Г. Митрофанов. - Таллин : [б. в.], 1990. - С. 56-61.

9. Сухомлинський В. О. Розмова з молодим директором // Вибрані твори : в 5 т. Т. 4. - К. : Радянська школа, 1977. - С. 391-626.

10. Сухомлинський В. О. Як виховати справжню людину // Вибрані твори : в 5 т. Т. 2. - К. : Радянська школа, 1977. - С. 149-416.

\section{References}

1. Bex, I. D. 2003. Vykhovannya osobystosti. U 2 kn. Kn. 2 : Osobystisno-oriyentovanyy pidkhid: naukovo-praktychni zasad [Upbringing of the person. In $2 \mathrm{kn}$. Kn. 2: Personality-oriented approach: scientific and practical principles]. Kyiv: Lybid.

2. Dolyns'ka, L. V. 2005. Psykholoho-pedahohichni umovy efektyvnoyi vzayemodiyi vykladachiv i studentiv $\mathrm{v}$ umovakh tradytsiynoyi osvity [Psychological and pedagogical conditions of effective interaction of teachers and students in the conditions of traditional education]. Scientific notes to the Institute of Psychology name. H. S. Kostiuka APN of Ukraine, 26, 2, pp. 8-11.

3. Ivanova, T. V. 1995. Profesiyna kul'tura maybutn'oho vchytelya [Professional culture of the future teacher]. Pedagogy and Psychology, 2, pp. 86-93.

4. Leont'ev, A. A. 1979. Pedahohycheskoe obshchenye [Pedagogical communication]. Moscow: Knowledge.

5. Kan-Kalyk, V. A. 1987. Uchytelyu o pedahohycheskom obshchenyy [About pedagogical communication for teacher]. Moscow.

6. Kilichenko, O. 2003. Ihrovi metody stymulyuvannya navchal'no-piznaval'noyi diyal'nosti maybutnikh uchyteliv pochatkovykh klasiv [Gaming methods for stimulating educational and cognitive activity of future primary school teachers]. 1st Grade School: Theory and practice, 7, pp. 184-189.

7. Pashchenko, D. I. 2001. Henezys humanistychnykh idey u pedahohitsi [Genesis of humanistic ideas in pedagogy]. Kyiv: The scientific world.

8. Mytrofanov, K. H. 1990. Uchenychestvo kak realyzatsyya subzektnosty uchenyka $v$ pedahohycheskom obshchenyy [Discipleship as the realization of the student's subjectivity in pedagogical communication]. Tallinn.

9. Sukhomlyns'kyy, V. O. 1977. Rozmova z molodym dyrektorom [Conversation with a young director]. In: V. O. Sukhomlyns'kyy, 1977. Selected Works. Volume 4. Kyiv: Soviet school. pp. 391-626.

10. Sukhomlyns'kyy, V. O. 1977. Yak vykhovaty spravzhnyu lyudynu [How to bring a real person]. In: V. O. Sukhomlyns'kyy, 1977. Selected Works. Volume 2. Kiev: Soviet school. pp. 149416. 